\title{
From Subsistence to Property: Traces of a Fundamental Change in Early Modern Bavaria
}

\author{
Renate Blickle
}

0 UBSISTENCE and property." This paper looks at an enduring subject from a Central European perspective. It is an historiographical variation of an old matter of dispute: to whom do the goods of the world legitimately belong, to those who need them, or to those who possess them legally, but do not need them? In this paper "subsistence" stands for the legitimizing power of the idea of "need," and "property" for justification through an appeal to freedom. In theory more than two thousand years ago the question was already answered in favor of the primacy of property. When, in a fable related by Xenophon, an older boy traded his small coat for the large one owned by a small boy, and satisfied both of their needs, Xenophon condemned him. For, in doing so, the older boy violated the law of property. ${ }^{1}$ In practice, the legal sensitivities of most people naturally would have led them to resolve this difficulty in another manner. Even in the cultures of the North Atlantic, where today the primacy of property is vehemently defended and is considered the expression of individual freedom in its highest material form, people chose a different solution in earlier centuries. Paternalism in England, the forerunner of the European "PossessiveMarket-Society," according to Macpherson, was pushed back by liberalism only two hundred years ago. ${ }^{2}$ Elsewhere Polanyi's "Great Transformation" occurred at an even slower pace. ${ }^{3}$

The developments which pointed in the direction of modernity have, in my opinion, aroused decidedly more interest in the historical literature

This paper was presented to the Annual Meeting of the American Historical Association, 27-30 December 1987, in Washington D.C. It was translated by Thomas Robisheaux of Duke University, Durham, North Carolina.

1. Xenophon, Cyropaedia, ed. A. Goodwin (1879), 1:3.

2. C. B. Macpherson, The Political Theory of Possessive Individualism: Hobbes to Locke (Oxford, 1962).

3. Karl Polanyi, The Great Transformation (New York/Toronto, 1944). 
than did the understanding of the structural framework of the old order. To mention only one catchword, capitalism, and its formation and its peculiarities, has fascinated scholars. The developments which came before it, however, often have been treated only insofar as they explain the origins of capitalism or as they delineate more clearly the evolution of modern conditions which are thought to be more interesting. In the work of Werner Sombart, for example, one finds the appropriate and striking "concept of subsistence"- the "Idee der Nahrung"-which for him was the governing principle of precapitalist economic regulations. ${ }^{4}$ But this idea was obviously more a product of intuition than analysis. He did not describe it or develop it further, but instead used it to serve his immediate purposes: The "old" idea of subsistence served Sombart primarily as a way to identify the "new" signs of capitalism.

A counterpart to this position-equally close to the subject of this paper-can be found in the work of E. P. Thompson. ${ }^{5}$ He focused precisely on the traditional patterns of thought of the English lower class. Their attitudes were deeply influenced by the "ideal of needs." Thompson characterized them with his well-known phrase, "the moral economy of the crowd," and he interpreted it as a remnant of the older social concept of paternalism, which had embraced the whole of society, and which the authorities had been obligated to support and promote.

Thompson based his views on an analysis of social unrest. I see this approach as exemplary in elucidating the key social ideas of the past. My own reflections on this theme of "subsistence and property" (that is, of a social order legitimized either by an appeal to the "principle of needs" or to the "notion of freedom") also rest on sources left behind by earlier social and political conflicts. In this case they are the disputes in Bavaria between the subjects, communally organized, and the feudal authorities of the principality. My first thesis is this: The study of "popular conflicts" demonstrates the importance of the key social value of a "fitting subsistence," a concept which is to be found in the sources as the term Hausnotdurft, or "domestic necessity." This social value expressed a fundamental concept of order which received its legitimacy from the "principle of needs" and which was rooted in positive law and applicable to all social orders. My second thesis suggests that the decline of the "principle of needs" after 1700 was related to the development of liberal ideas, especially liberal conceptions of property. ${ }^{6}$

4. Werner Sombart, Der modeme Kapitalismus (Munich/Leipzig, 1928), vol. 1, 2d ed., Die vorkapilalistische Wirtschaft.

5. E. P. Thompson, "The Moral Economy of the English Crowd in the Eighteenth Century," Past and Present 1 (1971): 76-131. Idem, "The Moral Economy Reviewed," idem, Customs in Common (London, 1991): 259-351.

6. For more detailed references see Renate Blickle, "Hausnotdurft. Ein Fundamental- 
I want, first of all, to give you a brief, but hopefully also a relatively concrete, look at the existence and the social power of the idea of the term "domestic necessity," necessitas domestica in Latin.

To a certain extent the concept of "domestic necessity" can be seen at work in its role within the context of labor services. The performance of labor services provided by far the most common occasion for dispute between the communes and their noble or ecclesiastical lords. Toward the end of the eighteenth century, according to the information of one contemporary, there were virtually no nobles in the land who were not involved in a dispute over labor services. These labor services were not fixed in number or kind; the number of work days a lord could demand from his subjects was nowhere clearly laid down. That does not mean, however, that such demands could be made arbitrarily or without restraint. The yardstick for measuring labor services in Bavaria was "domestic necessity."

The Bavarian lawcode of 1616 defined the normal labor services in the territory in the following way: Labor services include those services and work that subjects must perform manually or with their draft animals for the "domestic necessity" of their respective lords. And it goes on to stipulate that this labor was permissible only insofar as it did not hinder subjects from securing "their own subsistence and that of those dependent on them." The leading legal commentary on this lawcode summed up all of the provisions concerning labor services in the following way: "In the end the general rule is set down that peasants who provide unfixed labor services should be treated so that they can still work their fields and meet their "domestic necessity.'"

In the legal provisions concerning labor services the concept of "domestic necessity" - or rather "subsistence" — was used as a standard both in the form of the "domestic necessity" of the lord, and also the "domestic necessity" of the peasant. Between these two lay the range of permissible labor services. The standard for the "domestic necessity" of the lord was supposed to limit labor services to those meeting the needs of the lord's house; the standard for the "domestic necessity" of the peasant was supposed to guarantee that the peasant farm still could muster the labor power necessary for existence. I would like to call attention here to two broad-ranging consequences of this "concept of needs." "Needs" as a norm were limited to that which was necessary for

recht in der altständischen Ordnung Bayerns," in Grund- und Freiheitsrechte von der ständischen zur spätbürgerlichen Gesellschaft, ed. Günter Birtsch (Göttingen, 1987), 42-62, and Renate Blickle, "Nahrung und Eigentum als Kategorien in der ständischen Gesellschaft," in Ständische Gesellschaft und soziale Mobilität, ed. Winfried Schulze (Munich, 1988), 73-93. 
life; and, at the same time, as a social value, it justified these necessities. The need requirements of the household were essential for existence, and must therefore be provided for. It erected, on the one hand, a protective wall against poverty and, on the other, another one against excess, a term implying above all else usury and luxury.

Conflicts over labor services in Bavaria provide a glimpse into the origins, the practical application, and the effectiveness of this concept. As early as the fifteenth century one can see that the "domestic necessity" of the peasant was used to restrict the labor demands of the lords. Conflicts over the demand for forced servant labor in the households of the lords were resolved by assuring peasants that they did not have to send their children to work for the lord if they "require[d them] for their work and needs at home." In the sixteenth century the limitation of labor services to those who met the needs of the lord's household played an important role. The basic principle - that a peasant must work only for the lord's "needs," and not for his advantage-became evident in these conflicts, and was eventually written into the lawcode of 1616 as "the standard of domestic necessity" that I cited earlier. Nevertheless it was still necessary to oversee compliance with the law. Numerous examples from every century are known to us showing how the nobility and the clergy who resided on the land and on their estates attempted to expand their own agricultural enterprises with the help of labor services. Where this did not happen, where, on the one hand, numerous domains remained modest in size, and, on the other, the mass of the peasantry remained intact, the standard of "domestic necessity," the concept of a "fitting subsistence" for the lord and for the subject, was responsible. This social standard worked with equal effectiveness in restricting the expansion of the lords' craft industries. Products that were not produced for household consumption, but were intended from the start for sale and for the market, could not be produced with labor services. In practice the boundaries were very vague, and, at the same time, extremely difficult to draw. Let us take a typical Bavarian example: the brewing of beer by princely and ecclesiastical breweries. As the disputes with the authorities suggest, lords who brewed beer succumbed continuously and easily to the temptation to require their peasants to provide carting services to transport barley, hops, and wood, or to render similar work in the form of labor services, since precisely this type of labor counted as normal and legal labor services so long as it served the household needs of the lord. The peasants' ever watchful eye and readiness to enter into a dispute were therefore preconditions for the practical application of the principle of "domestic necessity."

As a social norm the principle of "needs" had two adversaries: profit- 
notoriously and quickly denounced as usury - and luxury, that is consumption beyond one's needs. Since the norm already implied a standard of "one house," luxury naturally was judged to be everything which exceeded the needs of this single unit. The labor services that a noble lord demanded in order to build or to provision a second house, such as a residence in the town or a pleasure castle, were therefore refused, and also legally forbidden with arguments against superfluous luxury. As one can imagine, the boundary between "domestic necessity" and luxury could literally run right through the middle of the lord's gardens. If one planted a castle garden for "such things as were needed daily in the kitchen," certain labor services could then be rendered. If a lord were "to make a pleasure garden" out of it, however, his subjects were not obligated to work there, or so the council of the prince determined in 1594.

The relationship between labor services and "domestic necessity" that I have briefly sketched illustrates the development and function of the idea of a "fitting subsistence" by way of only a few points and examples. One can also discover "domestic necessity" as a norm, as the basis for legal claims and rights in the regulation of common fields and forests, or in the economic and sociopolitical measures of the Bavarian princes. In princely mandates of the fifteenth century the principle of "domestic necessity" was already a privileged one and applicable to all estates. The principle applied to "every countryman, whether of high or low estate, who had a house on the land," that is, to prelates, nobles, officials, townsmen, or peasants.

To recapitulate I would like to emphasize five points.

1. The term "domestic necessity" described in Bavaria a legal norm which distributed economic resources in this society of scarcity according to the principle of needs.

2. The principle of needs had validity as a legitimate legal claim, and was expressed characteristically as "needs," or Notbedarf. It could provide social legitimacy to peasants who resisted the authorities in the early modern period.

3. The actual scope and content of the "principle of needs" was bound up with the concept of the house. Neither the individual nor a privileged estate or class, but the household community, the house-all houses in the land-could appeal to the principle of "needs." Insofar as this was true the social order of Bavaria rested on foundations that were egalitarian and not consistent with the society of orders.

4. This seeming equality of all households in principle did not contradict the fact that one's needs were to be measured according to the status of the head of the household and the size of his house. Needs were to be "fitting," or proportional. Every peasant or noble did not have the same 
needs. "The standard is to be applied," the commentary on the law code reads, "so that the bird is to be measured by the nest."

5. The norm of "domestic necessity" subsumed unto itself the categories of suitableness and equality. It combined the hierarchical conception inherent in a society of orders with the egalitarian right of existence within the framework of the traditional European order.

In reality the form that "domestic necessity" actually took in Bavaria was a product of disputes carried out by major social groups after the fourteenth century. At first it was based on only a vaguely elaborated set of values citing the notion of need. The zenith of its power to legitimize social relationships came in the sixteenth and seventeenth centuries. By the end of the seventeenth century there were already signs that its star was beginning to fade. Its decline was directly connected to the rise of liberal thought within the constellation of social values.

In the second, and shorter, part of my article, I would like to show you this slow change from a concept of order based on "needs" to one rooted in the idea of "freedom." I want to describe for you three scenes, three situations, one each from the sixteenth, seventeenth, and eighteenth century. In each of them I will contrast the idea of "domestic necessity" with the then current conceptions of property.

Our first example from the sixteenth century looks at a dispute between the townsmen of the market town of Altomünster and their lord, the monastery of Altomünster. The townsmen had lodged a complaint against the monastery with the prince of Bavaria because the abbess, in the townsmen's opinion, had chopped down and sold off too many trees from the neighboring woods. The town had the right to meet its needs for supplies of wood from this forest; the monastery was described as the owner of the forest. The townsmen based their complaint on the argument that the monastery, through its tree-cutting, endangered their "domestic necessity," their "fitting subsistence." Against the monastery's right to the property they opposed their own right to a secure supply of wood. The townsmen's right to have their needs met, therefore, restricted the property rights of the monastery, and not simply in the material sense of reducing the monastery's share of the wood, but also in a categorical sense by rejecting the idea of the monastery's right to dispose freely of its own property. In the sixteenth century the "principle of needs" dominated the "principle of property."

In the second example about one hundred years later, around 1680, a shift was evident in the balance of power between the "idea of needs" and the "idea of property." The parties in the dispute were the peasantry of Ammergau and their lord, the monastery of Ettal. The Ammergauers 
also intervened against the felling of trees by the monastery in a nearby forest, but they argued differently from the townsmen of Altomünster a century earlier. They did not defend their needs for wood, but instead asserted that they were the owners of the forest. The Ammergauers demanded that the forest should remain, as they put it, "at their free disposal." They wanted to manage it with "complete freedom." Their argumentation and choice of words in the dispute over the forest shows that they had overcome the traditional concept of property, and developed a new concept of property resembling the modern idea of private property in all of its essential features. The monastic authorities argued otherwise. Ettal asserted its rights as the owner of the forest, to be sure, but it understood that to mean something different from the claim of the Ammergauers. The monastery clung to the traditional conception of property. It was satisfied with that older form of imperfect ownership which was still limited by the claims of their subjects based on need and their use rights to the property. This did not alter the fact that the dominant social ideas had changed before 1700 as the idea of property found broader acceptance.

The third example in this small cycle of illustrations of the theme of "subsistence and property" depicts the social dominance of the idea of property in the middle of the eighteenth century. The opponents this time in a dispute over a forest were the town of Ohlstadt and its lord, the monastery of Schlehdorf. Both of them asserted that they were the owners of the forest, and both had left behind them the old framework of thought that supported incomplete or divided property rights. The commune thought that the monastery was not due even "the smallest right" to the forest. The monastery likewise held that it alone was the unrestricted and sole owner of the property, since, as the provost argued learnedly, "Duo domini in uno eodemque subjecto consistere non possunt." Securing the peasants' need for wood, meeting the needs of the household, appeared only as a marginal problem in this dispute. The provost recommended to the peasants that they petition him for wood when they wanted it for "domestic necessity." The right to secure "the household's domestic necessity" appears to have lost its power. In any event, the idea of property had been freed from the shackles which the principle of need had imposed upon it. The solution to the Ohlstadt dispute shows up the new situation clearly: The disputed forest was surveyed and then divided; the claimants, the monastery and the commune were each awarded a part as their "own private property," as one now called it. After 1756 the new private owners disposed over their own parcels of forest with complete freedom. 
The background of the conflicts described here was shaped by a concept of "divided property," i.e., an ideal construction which was intended to circumscribe the relationship of men and land in legal terms. According to its origins property was ownership of real estate, and for this reason the locus classicus of "divided property" was the farmstead. Thus a farmstead in early modern Bavaria usually belonged to two proprietors, each with different property rights: The seignorial lord was considered to be the "superior proprietor" (dominus directus), and the peasant was seen as the "using owner" or "inferior proprietor" (dominus utilis). Attempts were made to see the legal status of forest land in analogy to these property rights, but in many places the rights to forests remained undefined until the seventeenth or eighteenth centuries. Gradual changes of meaning that occurred in the concept of property were developed more easily in the area of the imprecise rights to forest land than in the area of the written and contractual fixed rights related to farmsteads. New developments can be recognized earlier here.

In this phase of change both owners of the cooperatively owned property strove to eliminate the other partner. Each wanted to enjoy sole proprietorship, free from encroachments by the other, and to be able to dispose of property freely. Around the middle of the eighteenth century this goal was reached. At that time, as demonstrated by the example of Ohlstadt, the property both parties were contending for-the forest land-was parceled up and the actual parcels were portioned to the contestants. From this point on the rights of both proprietors were no longer qualitatively different; now they were identical. Between proprietors of this new sort were no shared claims to property and no mutual rights or duties. The traces of "public authority" which were visible as a kind of lordship right in the "superior proprietorship" had disappeared. Property as a private right did not include any kind of responsibility toward another person. It was the legitimate right of its owner regardless of the needs of any others.

In the nineteenth century this form of private property became predominant. The civil individual saw his property as a material guaranty and a manifestation of his freedom, and elevated it into a sacrosanct human right. Of course this does not mean that the controversy over the concept of property and the right to subsistence-that is the right to satisfy the basic needs of daily life-was laid to rest once and for all. This controversy is being continued today in the sphere of human rights. Added to the liberal rights of citizens were the basic social rights, the so-called human rights, of the second generation. In the twentieth century even the liberal concept of private property itself was no longer 
beyond bounds. Thus the Constitution of the Federal Republic of Germany requires that property be used, not by the individual for himself alone, but "also for the benefit of all": "Property obligates."7

BERN, SWITZERLAND

7. Basic law for the Federal Republic of Germany of 23 May 1949, article 14, paragraph 2: "Eigentum verpflichtet. Sein Gebrauch soll zugleich dem Wohle der Allgemeinheit dienen." 